\title{
ІСТОРИЧНА УРБАНІСТИКА
}

УДК $94(477.8)$

\section{COMPREHENSIVE DEVELOPMENT AND ARCHITECTURAL AND ARTISTIC DESIGN OF IVANO-FRANKIVSK DURING "DEVELOPED SOCIALISM"}

\author{
Олег МАЛЯРЧУК \\ Івано-Франківський національний технічний університет нафти і газу, \\ кафедра філології та перекладу, \\ вул. Орищака 7, 77300, м. Калуш, Івано-Франківська обл., Украӥна \\ e-mail: oleg.malyarchuk@gmail.com \\ DOI: 10.15330/gal.33.126-136 \\ ORCID 0000-0002-3019-9028
}

У статті охарактеризовано зміни, щзо відбулися внаслідок соиіалістичної індустріалізації західних областей Украӥнської РСР на прикладі Івано-Франківщини й пов'язаною з нею урбанізацією. Архітектура міста Івано-Франківськ (Станіславова, Станіслава) увібрала зрізи иілих історичних епох. Радянський період в історї міста характеризувався своїми відмінними від усіх інших стилів архітектурними рисами та масштабністю забудови. Урбанізація Івано-Франківська, Тернополя, Чернівців, Ужгорода, а особливо Львова є унікальною в історичному досвіді. Вона є “запізнілою” $і$ їй передувала докорінна воєнна і повоєнна зміна етносоціального складу населення міст, де домінуючу більшість становили євреї $і$ поляки. Стрімке зростання чисельності міських мешканців західного регіону республіки відбувалося за рахунок украӥнського сільського населення. 3-поміж інших великих українських міст ІваноФранківськ вирізнявся тим, щчо був одним із не багатьох обласних ичентрів (поступався Львову), щчо украӥнізувався та відіграв визначальну роль в національно-релігійному русі другої половини 1980-х років.

Мета дослідження - в історичному контексті проаналізувати специфіку архітектурно-художнього оформлення, благоустрою міста Івано-Франківська в період панування радянської тоталітарної системи ("розвинутого сочіалізму”), успіхи і прорахунки. Завдання: 1) довести, щзо історичній частині міста внаслідок радянської реконструкиї було завдано непоправимої икоди. Багато старих будинків після профілактичного ремонту могли експлуатуватися ще десятки років. Вони повторили долю свої колишніх власників, котрі у своїй більшості були фізично знищені; 2) узагальнити здобутки і недоліки у практиці житлового, промислового і комунального будівництва на прикладі непоодиноких випадків, коли на території нової забудови (кварталів, мікрорайонів $і$ навіть цілих населених пунктів) мешканці не забезпечувалися найнеобхіднішими елементами благоустрою. Істотні недоліки допускалися у справі озеленення.

Для розробки теми, автори використали иุілу групу наукових методів: принципи об 'єктивності та історизму, що передбачають розгляд окремих явищ і процесів у їх розвитку та тісному зв'язку із системою відповідних суспільних відносин; історичні факти розглядаються на фоні політичних процесів, щуо передбачає застосування методу порівняльного аналізу, завдяки якому з'ясовано сутність багатьох знакових для украӥнської суспільно-політичної думки подій. Проектні і будівельні організації при спорудженні житлових комплексів не завжди дбали про збереження природного рельєфу, рослинного шару, зелених насаджень. Роботи з благоустрою міст, селищ і сіл громадськість проводила систематично. Партійно-радянська влада намагалася усі досягнення у цій справі записати на свій рахунок. Обласний цуентр Івано-Франківськ здобув славу красивого міста. У свій час він займав призові місия у змаганнях з благоустрою серед міст України. Цю славу мешканџі міста зберігали та примножували незважаючи на несприятливі політичні умови тоталітарної системи иляхом творчого підходу до оновлення і розширення міста, уважного і бережливого ставлення до існуючої капітальної забудови та природи.

Ключові слова: архітектурні стилі, м. Івано-Франківськ, комплексна забудова, жилі масиви, благоустрій, озеленення.

Stanislav (since November 9, 1962 - Ivano-Frankivsk), as well as Lviv, Chernivtsi, Ternopil, Lutsk, Uzhgorod and other cities and towns of the western regions of the Ukrainian SSR had their own urban planning traditions that have developed over the centuries. Artistic urban trends of the 
XIX-XX centuries were reflected in government and sacred buildings (Neo-Renaissance, NeoBaroque, Neo-Gothic), industrial facilities in Kalush, Drohobych, Boryslav take a special place. The defining feature of urban architecture in Western Ukraine was the lack of minimalism. Usually, various elements of classical architectural models (mostly historicism and eclecticism) were freely combined. Thus, in Ivano-Frankivsk, the railway station is decorated with elements of the Moorish style, and narrow semicircular windows and ribbed columns created a laconic and at the same time elegant Neo-Renaissance style. A luxurious building of the Directorate of Railways in Stanislaviv was erected in the style of Viennese classicism. Now it is the main building of the medical university. At the turn of the century, the Austrian Empire was conquered by a new style - The Vienna Secession. Gradually, a new style became dominant in Europe and reached the towns of Galicia. The combination of Romanesque, Byzantine and Cossack Baroque styles, which went down in history as the Ukrainian architectural style (Ukrainian version of Art Deco), can be traced in the monastery building and the school of the Basilian Sisters in Ivano-Frankivsk.

Early twentieth century contributed to the development of the latest design techniques and elements of construction. Widespread use of steel and concrete led to a new style - constructivism. Architects began to use new materials more often and implement the latest advances in construction. When designing a certain building, the architect put in the first place its practical purpose, using a new building arsenal of structures. Stanislav's pre-war architecture took the form of modernized neoclassicism, manor style, Art Deco, partially preserved romantic and folk trends.

In the 1950s, Soviet architects still used various decorative elements in public building projects. In the early 1960s, the Central Committee of the CPSU condemned "adorning". If earlier the construction of structures with columns and arches was allowed, which in turn led to an increase in the cost of work, then during the N. Khrushchev's party and country administration, this was abandoned. Elements of different styles have received the negative designation "quirks". Soviet architects were forced to reconsider their previous approaches and abandon "excesses". In this regard, there had to be rejected two projects in Nadvirna, three in Odessa, and two in Dolyna ${ }^{1}$. In line with the new requirements for construction work, all the plasterwork, as well as the minimum cost of landscaping were rejected. Typical small-scale projects became dominant, which were tested in all republics and recommended for the Stanislav Oblast.

Domestic scientists have revealed a picture of socio-economic, urban planning and environmental processes that took place in Ukraine and its western part in the twentieth century. These are the scientific works of V. Baran ${ }^{1}$, S. Vasyuta 2 , Y. Humen ${ }^{3}$, V. Klapchuk ${ }^{4}$, O. Malyarchuk ${ }^{5}$ and others. However, these publications cannot be considered sufficient and exhaustive. Several issues remain understudied: reconstruction of old and construction of new industrial enterprises, agriculture, urban housing and communal services, operation and preservation of housing, overcoming the negative effects of industrialization and collectivization, changing social structure and usage of labor resources, industry diversification in the late XX century and many others.

The purpose of the article is to analyze in the historical context the specifics of architectural and artistic design, improvement of the city of Ivano-Frankivsk during the rule of the Soviet totalitarian system ("developed socialism"), successes and failures. The object is the socio-economic policy of the party-Soviet government. The subject is the features of its implementation in the regional center of Prykarpattia - Ivano-Frankivsk.

\footnotetext{
1 . Баран В. Україна: новітня історія (1945-1991 рр.). Львів : Інститут українознавства ім. І. Крип’якевича НАН України, 2003. 670 с.

${ }^{2}$ Васюта С. Радянський екоцид в Україні: історичні витоки та труднощі подолання. Тернопіль : СМП “Астон”, 2000. 536 с.

3 Гумен Ю. Урбоекологічні проблеми Західного регіону України 1960-1990 рр.: історичний аспект. Тернопіль : Вектор, 2008. 264 с.

${ }^{4}$ Клапчук В. Корисні копалини Галичини: видобування та переробка. Івано-Франківськ : Фоліант, 2013. 508 c.

${ }^{5}$ Малярчук О. Соціально-економічні процеси в західному регіон Української РСР (1964-1991). ІваноФранківськ : Симфонія форте, 2015. 548 с.
} 
In the first postwar years, the old housing stock was mostly restored, and neither materials, nor equipment, nor funds were enough to build a new one. According to the approved plan "On the improvement and reconstruction of the city of Stanislav" from March 30, 1945 during one year the subject to restoration were 422 houses with an area of $48000 \mathrm{~m}^{2}$, which required major and "medium" repairs. The archives of the party's regional committee state that "the stencils of the new city street names and house numbers were not made by the city committee, the city street names remained the same, as they had been during the time of aristocratic Poland and the German occupiers. In the city one can observe streets with all sorts of names: streets of St. Joseph, St. John, St. Stanislaus, etc. Despite the fact that the city of Stanislav was liberated from the German occupiers for about a year, city organizations (leaders) did not even have time to change the names of streets and remove old signs from shops that exist today - for example, "Oseledtsi moskali! (The European anchovy!)", "Narodna torhivlia (People's Trade)"”.'.

The Planning Commission of the Ivano-Frankivsk's Executive Committee keeps statistic data proving that in 1949, 4 houses for 48 apartments were commissioned in the regional center, and two years later -3 for 13 apartments. Two decades later, the inhabitants of the Ciscarpathian region "were already used to the scale of housing construction. Thus, in 1975, 20 multi-storey buildings with 1,709 apartments and 2 dormitories with 852 beds were put into operation in Ivano-Frankivsk. Building companies of the city spent 8.4 million rubles on housing construction. A completely new city of chemists has grown - Kalush ("Salt city") with a population of over fifty thousand people. Large modern residential areas have been built in Kolomyia, Dolyna, Nadvirna and Burshtyn. Only for four years of the ninth five-year plan in the cities of the region, 756 thousand $\mathrm{m}^{2}$ of residential area ${ }^{7}$ were put into operation. Similar changes quickly occurred in other cities of the Western regions of the Ukrainian SSR.

Kyiv State Institute of Urban Design (Dipromisto) in 1955 completed the preparation of the general plan of Stanislav and determined the prospects for its further development. In 1959, the planning of the "industrial district" of the regional center was completed. According to the new Soviet architectural approaches, the city was zoned. Construction and reconstruction should be carried out in micro districts with the creation of an extensive network of cultural and household institutions. At the same time, it was planned to move several small industrial enterprises, warehouses, and other facilities from residential areas to industrial zones. To reduce the intensity of automobile traffic in the city center, it was planned to move the routes for transit transport outside of the city, and to build bypass roads for urban vehicles. At the same time, the directions in the management of landscaping and planting of greenery were determined. Due to the diverse changes in the economic development of the city and the region, as well as in the city-planning practice, the master plan needed a certain correction ${ }^{8}$.

In the mid-1960s, 4-5 storey houses prevailed in Ivano-Frankivsk. In 1967, the construction of height-different buildings began on Naberezhna Street, at the end of Halytska street. In 1966, the construction of 70-apartment buildings on Halytska Street was already in progress. At the same time, a complex of pre-school institutions with 280 places was built. In the 1970s, construction of a 9-storey building on Kuibyshev Street began. The main streets: Radianska, Dzerzhynskoho, Daduhina were gradually reconstructed. In 1966, the construction of 70 apartment buildings began on Radianska Street (behind the railway bridge). The facade of the street (the artist's house) was on the corner with Ivan Franko Street (designed by architects L. Lukomsky and I. Hryniov), Kosmos cinema and others. The construction of a 7-storey hotel, a new department store, a trade union building, a new laundry, and a 7-storey building of the Agricultural Machinery Association "Silhosptekhnika" began the following year.

\footnotetext{
${ }^{6}$ Довідки, інформації відділів обкому партії, міськкомів, райкомів партії, обласних організацій про виконання постанов червневого (1945р.) Пленуму ЦК КП(б)У, бюро обкому партії про розвиток промисловості, благоустрій м. Станіслава, заготівлю, завіз палива, розвиток сільського господарства. 20 березня - 30 грудня 1945 р. ДАІФО. Ф. П-1. Оп. 1. Спр. 262. Арк. 18, 21.

${ }^{7}$ Житло - добро народне. Прикарпатська правда. 1975. 13 травня.

${ }^{8}$ Стенограма зборів активу обласної партійної організації про хід та розвиток житлового будівництва в області від 22 серпня 1957 р. ДАІФО. Ф. П-1. ОП. 1. Спр. 2075. Арк. 49.
} 
Affiliated and cooperative construction were gaining momentum. In 1966, at the expense of a number of organizations the construction of a 129-apartment building on Halytska Street began. To this end, cooperatives were established for the construction of three 70-apartment houses at the expense of individual developers. Economic calculations have shown the feasibility of using largescale cement-concrete slabs in the improvement of streets. A great amount of inconveniences and expenses were caused by carrying out any communications when it was necessary to remove (destroy) an asphalt covering of roads and sidewalks. The slabs, on the other hand, are easy to remove and put them in place after finishing.

New principles were introduced in the landscaping of residential areas. Replacing annual flower beds with lawns with groups of perennials not only gave the streets an attractive appearance but also required less money. More and more attention was paid to landscape architecture, ie the planned landscaping of the city. I. Bodnaruk, the landscape architect of the city, developed sketches of the square near the post office. According to the new post office building, the square was also rebuilt. Plantings of spruces and other ornamental plants were quite appropriate here. In 1966, some attention was paid to the vertical landscaping of houses. Some samples have been preserved in the city, such as the former building of the regional executive committee.

In the center of Ivano-Frankivsk in the mid-60s of the twentieth century. rose the first highrise building in the city - the main post office. It was erected so that it could be seen all over the main Soviet street. The whole ensemble of houses, which began with a house on the corner of Sovetskaya and Chapaeva streets (fashion studio) and ended at the intersection of Halytska Street and Moskovska Street (Verkhovyna deli), was completely "read" from Radianska Street. The plantations were not supposed to cover the works of urban architecture, but on the contrary, to emphasize their interesting beautiful fragments.

At the beginning of 1968, more than 2 million $\mathrm{m}^{2}$ of housing in cities and 76,000 houses in villages were built by the selfless work of the residents of Ivano-Frankivsk region ${ }^{9}$. In the industrial centers - Ivano-Frankivsk, Kalush, Dolyna, Nadvirna, Kolomyia, Burshtyn, new neighborhoods, and neighborhoods of a new style of architecture have grown. However, settlements were not always built up, as required by Soviet requirements and instructions governing building, landscaping, landscaping, and exterior design. Numerous staff of officials - heads of district executive committees, chairmen of city and settlement councils, architects of cities and districts, heads of communal farms, directors of utilities, house managers, employees of design organizations, and sanitary-epidemiological stations, heads of various organizations and enterprises own considerations and interests. Thus, the verbal issue of the newspaper "Prykarpatska Pravda", which saw the world on November 24, 1965, in the club of communal workers, was dedicated to the preservation of the housing stock and improvement of IvanoFrankivsk, in particular in winter conditions. It was attended by public utilities, repairmen, asset management, residents, representatives of party and Soviet bodies. The participants were read a share of letters from the editorial mail, which corresponded to the topic of the issue. The head of the city department of municipal services O. Nikolaev illustrated the performance with figures which showed that big means were spent on improvement of the city, arrangement of dwellings. For ten months of the current year, 157 thousand rubles were used for repair of streets, for the arrangement of inhabitants 935 thousand rubles. for the specified period, 29 streets were repaired by major and current repairs. If in Ivano-Frankivsk the situation with the current repair according to the then Soviet models was at the more-less good level, house management mostly coped with their work as well, the population and utilities filed large claims to repair organizations: repair-construction bureau \#1 and special repairconstruction bureau \#3. The terms of major repairs of hauses were quite extended. At the same time, many objects were repaired and their commissioning deadlines were violated. So, the second year the house on Lenin Street 29 was repaired. "Preserved" houses on Ostrovsky Street 17, Harkushi Street 15-b. Once again, the deadline for the completion of repairs of houses on Dzerzhynsky Street 74, and the number of others were determined. If to analyze the activities of repair-construction bureau \#1 and shortcomings in the work one may found out that the main drawback was bad labor organization,

\footnotetext{
${ }^{9}$ Народне господарство Івано-Франківської області. Статистичний збірник. Львів : Статистика, 1970.
} $182 \mathrm{c}$. 
weak control, theft of construction materials. The key shortcoming was that the work was carried out "on phone calls of officials", and not according to the schedule and the winter caught the worker "in a summer dress". Complex repairs were made by the method of sending workers to the place from where a complaint would come. The second key issue, around which there were a lot of talks, was the attitude of residents to the preservation of housing stock. In 1965 in the city, 294 residents repaired their own apartments. Thus, in the house on Karl Marx street, 17 residents completely repaired and prepared for operation in the winter the heating system and independently monitored its serviceability. Chairman of the House Committee of house management No. 5 com. Rylova said that on Lesia Ukrainka Street 7, on the initiative of a resident Kryzhavytska, the entire house - eleven apartments - was completely renovated by residents. But this is rather an exception to the rule. A significant part of residents did not preserve, but consciously or unconsciously destroyed housing, as it was obtained for free from the state. Typical examples: "residents forgot to close the taps and water flooded neighboring apartments. The employees of the Department of "Vodokanal", who arrived to the place of accident, removed from the pipes rags, bones, etc." 10 .

In 1967, work began on the certification of all housing in the region. A technical passport was created for each house, in which all the actual data about the house and changes were entered. The purpose of certification was to obtain a complete description of the state of the housing stock. This contributed to the proper preparation for major repairs.

The 1970s saw more than just quantitative growth. A lot of things has been done to make people's lives more comfortable. Thus, in Ivano-Frankivsk, for example, in the mid -1970 s, $83 \%$ of the housing stock was equipped with water supply and sewerage, almost half of the apartments were provided with central heating, more than two thirds - baths and showers, almost all apartments were gasified. High-rise buildings were built with elevators, garbage pipes, and other technical equipment. The scale of housing construction has been growing. Cities grew up, apartments became even better. In such conditions, one of the most significant problems was the correct and truly economic operation of the housing stock. The agenda included the proper development of the material and technical base of repair and maintenance services, their specialization, staffing, the introduction of progressive methods of work. A lot was done in this case, the base was repaired with new equipment, although in some cities there was still much to be done. The example was the Kalush Chemical and Metallurgical Works (KHMK), which owned 180 thousand $\mathrm{m} 2$ of departmental housing stock, but did not have a proper production base for operation and major repairs. On the pages of the press of that time it was noted that "the most disturbing thing is that we still have a lot of ugliness in the organization of work on the operation and preservation of the housing stock. Many houses are in a technically neglected state, with faulty roofs, gutters, engineering equipment, unattractive facades, entrances. In the cities of the region, there are 413 dilapidated houses with an area of 15.3 thousand square meters, threequarters of which are located in the regional center ${ }^{11}$.

On the one hand, there was nothing to be done, time was doing its own thing, and on the other, it wasn't just that. In Ivano-Frankivsk, a large harm to the housing stock was caused by unsubstantiated conclusions when selecting houses for major repairs. The old buildings of the city, bearing the imprint of previous historical eras and artistic styles, were excluded from the title lists under the pretext that they were to be demolished. The "living space" must be cleared for the new Soviet reality, including in urban planning. At that time, there was a thesis that "we are already used to it: every year, in place of old small houses that have already outlived their time, modern multi-storey buildings, entire blocks, grow up on new squares" 12 .

Some residential buildings have become "dilapidated" (in the emergency state). There was nothing accidental in this, since the regional housing administration did not provide for a clear longterm planning and system in the selection of houses for repair. Most of the party-Soviet nomenclature moved from the old to new houses of improved layout and closer to the city center or the place of their work. And the repair itself? Rarely did they adhere to normative deadlines. Therefore, the house on

\footnotetext{
${ }^{10}$ Бережімо наші житла. Прикарпатська правда. 1967. 10 грудня.

11 Житло - добро народне. Прикарпатська правда. 1975. 13 травня.

12 Політико П. "Місто росте вгору”. Прикарпатська правда. 1975. 20 квітня.
} 
Mateika Street 24, in the regional center, was in repair the whole year instead of five months provided by standard terms. Such cases, as evidenced by archival documents, were many. And this is not only the fault of repairers - many defects in technical documentation allowed the Department of the Republican Institute "Ukrzhytloremproekt". In 1975, only in the regional center, most of the issued projects were processed during the repair process, which delayed the progress of work and caused fair complaints from residents.

No less painful was another issue - water supply to the population. Water consumption in Ivano-Frankivsk per person increased, but it was less than the average for the Republic. In addition, the technological needs of industrial enterprises consumed more water than in other cities of Ukraine. Untimely repair of the corresponding equipment led to the fact that in the regional center more than two thousand cubic meters of water were lost daily. The pace of construction of water supply facilities lagged behind the development of the city. Materials of departmental inspections convincingly testified to the mass irresponsible attitude to the performance of their official duties of employees of housing maintenance offices and home management ${ }^{13}$.

Official propaganda claimed that in many sectors of the socialist planned economy, the centralization of management had a "positive effect". With centralized management, it was possible to organize the operation of housing more effectively, creating strong production bases for their repair. In the conditions of Ivano-Frankivsk region there were their own features-the houses were located in different departments ("Himmetalurhbud" trust, Burshtyn DRES, combine "Prykarpatlis", etc.). As a result, they were like "orphans" without proper supervision. Thus, over the past six years, only 65.3 thousand $\mathrm{m} 2$, or $4.2 \%{ }^{14}$, of the departmental Fund was transferred to the urban housing system.

There were 37 independent ordering customers in Ivano-Frankivsk. They did not have qualified personnel to perform the functions of the ordering customer. Therefore, it is not surprising that there were shortcomings in planning the development of the city, funds and material resources of construction organizations were dispersed. As a result, the objects were constructed in violation of the regulatory deadlines, and the rhythmic delivery of housing was not provided. This should be in line with the integrated development of the city. Projects of such development in Ivano-Frankivsk provided for the formation of five neighborhoods. However, the construction of socio-cultural, household and commercial facilities lagged sharply behind the construction of housing. Microdistricts were built up without preliminary engineering preparation of territories (water supply, Sewerage, heating mains, roads, entrances, etc.). the Resonant example was in the microdistrict on Dzerzhinsky street in the regional center, where the customer capital construction Department oblvikonkomupospishiv to settle four houses (310 families). But the territory has not been ordered for a long time, there are no access roads, shops, consumer services, etc. ${ }^{15}$.

There were significant shortcomings in the planning and organization of the development of Ivano-Frankivsk. They could only be eliminated by the efforts of interested organizations. The "first violin" in this case belonged to the main ordering customer - the capital construction Department of the regional Executive Committee. It was impossible to talk about the full implementation of the socalled all-Union "Orel method" in the city, since there was no single customer and a single performer. In turn, the "Zlobin method" in construction did not spread properly. The loss of working time was large, tower cranes and technikaprostoyuvali. The logistics system did not always meet the requirements of the day. The builders had serious claims to the management of technical equipment and special management of mechanized works of the plant "Ivano-Frankivskprombud". The quality of construction work was often low, which is why the architectural and construction control authorities delayed the acceptance of houses in operation.

New residential buildings were put into operation with defects and imperfections. Shortcomings were partially eliminated at the expense of funds allocated for the repair of housing stock. The-

\footnotetext{
${ }^{13}$ Стенограма зборів активу обласної партійної організації про хід та розвиток житлового будівництва в області від 22 серпня 1957 р. ДАІФО. Ф. П-1. Оп. 1. Спр. 2075. Арк. 39.

${ }^{14}$ Житло - добро народне. Прикарпатська правда. 1975. 13 травня.

${ }^{15}$ Стенограма зборів активу обласної партійної організації про хід та розвиток житлового будівництва в області від 22 серпня 1957 р. ДАІФО. Ф. П-1. Оп. 1. Спр. 2075. Арк. 44.
} 
refore, for four years of the ninth five-year plan, 145 thousand rubles were spent on this. These funds had a direct purpose - to repair old homes that could still serve people, but were used to fix the building companies' spoilage. The issue of the state, level of operation and safety of housing stock in the regional center, cities and urban-type settlements of the Ivano-Frankivsk oblast was repeatedly considered at meetings of the Bureau of the regional Committee of the Communist party. It approved measures aimed at ensuring proper maintenance of premises, improving the planning and design of capital repairs, and better organization of repair work. The regulations defined the specific tasks to be carried out by District Councils, Distict Public Servises Department, District collective farm but the command-administrative management system with its all-embracing bureaucracy was standing in the way.

In 1974, the first repair and construction Department of Municipal housing management was organized. It carried out planned ongoing repairs of apartments, fulfilled individual orders of tenants for repairs, and also eliminated accidents in water, lighting and sewer systems of the housing stock of the city of Ivano-Frankivsk. Previously, these functions were performed by housing departments. Combining their forces and resources was an effective measure to improve the productivity and quality of work of repair workers, for more reliable preservation of the housing stock. On average, a housing department repairman provided 180 rubles worth of work a month, but then, under the new conditions, he provided 315 rubles. This was facilitated by more competent organization of work, higher level of engineering training and mechanization, which are not available to the dispersed labor forces of housing departments. The Department created a solid production base: a woodworking shop, a concrete and mortar unit, a blacksmith shop, a tinplate and locksmith shop with new equipment, and also had their own vehicles. In comparison with 1974, the volume of repair and construction works for two years increased by 2.3 times and reached 1.3 million rubles. Based on the objectives of the tenth five-year plan, the administration, party and trade Union organizations of the Department developed measures to improve production efficiency and quality - the quality leaflet was introduced. It was provided to a crew, a team, or a separate worker along with the job order. In a special column, the work was evaluated by the worker himself, the master of management and the housing department and the apartment's tenant. Such an assessment of all stakeholders more fully reflect the true state of Affairs. For an "excellent" rating, performers received a $10 \%$ surcharge to the earned amount, for a "good" rating $-6 \%$. With a "satisfactory" rating, they had only the tariff rate. In addition, the names of excellent and good performers were entered on the honours board, they were marked with thanks in the orders. Material and moral incentives were aimed at achieving the highest quality in "socialist labor". If within two months the collective or individual employee for some reason did not pass the quality list or had satisfactory ratings in them, the administration sent such producers to the tariff and qualification commission for re-certification. In the quality sheet there was another important column - "Comments, wishes of the housing master, tenant". Therefore, along with the incentive function, it also served an informative and mobilizing ones. This was important for the administration and specialists. The expressed wishes suggested how to improve the organization and technology of repair work. This innovation had proven itself with a positive side ${ }^{16}$.

In the mid 1970s there was a need to transfer to local Councils all municipal facilities, whom they did not belong, to concentrate in the hands of city Council funds allocated by industrial enterprises and various organizations for the construction of services, installation of utilities, roads, etc. One must agree with the reasoned opinion of the instructor of the construction Department of the Ivano-Frankivsk regional Committee of the KPU, D. Akhmetenko: "This would allow us to conduct a unified urban planning policy that would be based on the rational use of land, water and other resources" ${ }^{\prime 17}$.

In many cities and towns, the construction of engineering networks, paving of streets and sidewalks, improvement of squares and parks, telephone, radio, external lighting, etc. were carried out in very limited amounts. Hard surfaces of roads, sidewalks and park alleys were often poorly made and as a result quickly destroyed. At the same time, progressive coating - concrete slabs, slabs made of colored material, which had a better appearance and met the requirements of the then road and park construction, were not used enough. Small architectural forms - kiosks, pavilions, stands, sculptures, showcases, light

\footnotetext{
16 Дятлов Д. “Листок якості”. Прикарпатська правда. 1976. 30 березня.

17 Ахметенко Д. “Місто - єдиний комплекс”. Прикарпатська правда. 1977. 14 січня.
} 
advertising, as well as fences, street lighting poles - were sometimes made without taste, without taking into account the General architecture of the streets. When creating parks, squares and boulevards in residential districts, they often ignored the requirements of landscape architecture. decorative trees and shrubs, climbing plants, perennial flowers, green fences and lawns were not used enough.

All works related to landscaping, urban greening, exterior decoration of the city of IvanoFrankivsk were coordinated and controlled by the city's architectural and artistic Council, which included architects, artists, sculptors, specialists in landscaping and landscaping. Its members performed individual projects on a voluntary basis and participated in their implementation. The art Council paid attention to the combination of architecture and decorative and monumental art in practice. An example of this combination of monumental painting with architecture can serve as a residential building of the regional consumer union on Halytska Street, cafe "Yunist" (The Youth). In these works, many initiatives were shown by artists M. Figol, A. Balyuk, and others ${ }^{18}$.

Next to the development of microdistricts in the city of Ivano-Frankivsk, there was also the construction of individual objects on vacant plots. The placement of such objects and their architectural and planning solutions required special attention in order not to disrupt the overall architectural ensemble of the old capital part of the city center (a combination of "old and new"). This task was handled by the Ivano-Frankivsk branch of Dipromisto. Each such building, integrated into the existing development, even nowadays differs in the characteristic features of urban planning of the Soviet time, despite the individual use of standard sections, which were a kind of experiment, the search for the best planning and aesthetic solutions for housing and public buildings. For example, an eight-storey building of an intercity telephone exchange, a 73-apartment residential building with a store "Kooperator" (The Cooperator) on Halytska Street, a 36-apartment building on Shevchenko Street, residential inserts on Valy (the Ramparts) and many others built into the ancient city, violated the architectural integrity and remind of the times of totalitarianism.

The family of "skyscrapers" in Ivano-Frankivsk in 1975 was supplemented with a nine-storey dormitory of the V. Stefanyk National Pedagogical Institute on Chkalov Street for 894 students. This type of dormitory was built in the city for the first time. The structure was developed by the Dipromisto branch on the basis of a project carried out the student design and estimate bureau of the Lviv Polytechnic Institute (chief architect S. Valevsky). The architectural and planning solution is based on a corridor scheme with a two-way location of premises. On eight floors, residential cells are designed, each of them consists of two rooms for three people each, a living room, a bathroom, and a sanitary unit.

Cabinets were built into the wall. Living rooms had a windowsill refrigerator cabinets for storing food. On all residential floors there were rooms for classes, kitchens, recreation areas with spacious loggias. On the first floor there were rooms for cultural work and a buffet. In the courtyard there was a sports town with volleyball and basketball courts and a tennis court ${ }^{19,20}$.

In 1977 "the last brick" was invested in the most "vital point" of the city - a twelve-storey building (171 apartments) on the embankment of the name. Stefanik. Two semi-detached houses built by "Prykarpatbud" trust, which was accounted for almost half of residential space area in IvanoFrankivsk. The largest scale of construction was carried out in the microdistrict at the end of Gagarin Street. The work was carried out on the construction of two nine-storey houses - a dormitory for 1286 people and a 144-apartment building. In addition, a large-panel house was under construction. Work continued on the design of the facade of the neighborhood: nine-storey, ceramic-tiled houses, along with shops and a block of consumer services, created a single whole composition ${ }^{20}$.

In the second half of the 70s of the XX century, the practice of "unified national economic complex" was introduced in urban planning. Instructor of the construction Department of the IvanoFrankivsk regional Committee of the Communist party of Ukraine D. Akhmetenko described the

\footnotetext{
${ }^{18}$ Рідного міста зростання. Прикарпатська правда. 1965. 30 листопада.

${ }^{19}$ Попиченко Л. “Як у рідному домі”. Прикарпатська правда. 1975. 20 липня.

20 Листування 3 міськкомами, райкомами партії, обласними організаціями з питань організаційно-партійної, ідеологічної роботи, промисловості, будівництва об'єктів промислового й соціально-культурного призначення. 21 січня 1980 р. - 5 лютого 1981 р. ДАІФО. Ф. П-1. Оп. 1. Спр. 4617. Арк. 104, 125.
} 
situation as follows: "The city of Ivano-Frankivsk is being built up by 26 enterprises and organizations. And everyone has their own "policy". Some save on "social culture", others are only concerned about expanding the territories of enterprises. This does not take into account the fact that their sanitary protection zone is significantly expanded and a significant part of the prospective residential area falls into it. The reconstruction of the locomotive repair plant is being carried out in gross violation... The company is located in the center of the city, in an area of dense old buildings, and allocate funds for its expansion - in any case, this is not a well-thought action. As for new enterprisesdevelopers, they sometimes shift from proportional participation in the development of the industrial center. For example, more than 55\% of capital investment has already been spent on the construction of industrial facilities at the Avtolyvmash plant, while only $15 \%$ has been spent on housing. What to does this discrepancy lead? It, firstly, hinders the comprehensive development of the city and, secondly, creates difficulties for the enterprises themselves in hiring permanent staff. Incomplete provision of housing and children's institutions causes staff turnover"21.

In the development of Ivano-Frankivsk, other mistakes inherent in the command and administrative system took place. The city's Executive Committee, city architecture, and the regional Department for construction and architecture did not always follow a clear and principled line on these issues. As a result, ten microdistricts were built up in the city at the same time. This practice led to an irrational use of the capacity of construction organizations, the dispersion of material and labor resources. Of course, in Ivano-Frankivsk and other cities, a lot has been done and done for its development, and some successful decisions. These include, for example, the creation of the Hryplyn industrial hub in the regional center. On the other hand, master plans were not always developed in such a way as to properly take into account the future development of the city. Industrial zones that occupied $40 \%$ of urban land were not planned in detail.

Thus, the development of Ivano-Frankivsk was determined by the specifics of economic and political development in the historical past. The central part of the city according to the new "Soviet approaches" had "many disadvantages": extremely dense location of buildings in the Central district, blocks fineness; most of the city's territory with all utilities was occupied by "low-value" single-storey buildings. It was economically advantageous to reconstruct these old areas - to demolish the "lowvalue" housing stock (the houses were occasionally in an emergency state), using the existing utilities, rather than to take the development out of the city. Reconstruction of these areas was carried out with the calculation of reducing the density of buildings, creating green areas. As a result of the reconstruction of the old historical part of the city, irreparable damage was caused. Under the old part of the city there was a large and very extensive system of underground passages.

With the commissioning of new construction projects, there was a question of their landscaping and urban greening. Collectives of enterprises and organizations, all residents did not stand aside at all, but took part in this nationwide campaign as much as possible. Of course, the improvement of landscaping and exterior design of cities and towns in the region depended on the Executive committees of local Councils of workers' deputies. These bodies were designed to do everything possible to make each locality beautiful, so that a person who first visited a particular Carpathian village or city would remember its streets and houses. In the "fight for cleanliness" in every city, in every village, all the inhabitants were included. The architecture of cities and towns has acquired new features. Green zones and recreation centers were created around the cities. However, a typical feature of the Soviet reality (the norm of life) was the catastrophic pollution of reservoirs, disregard for the rules and requirements of sanitation on the part of public utilities, managers of enterprises and collective farms.

\footnotetext{
${ }^{21}$ Дем’янчук С. “Курс на романтику”. Прикарпатська правда. 1976. 13 червня.
} 


\title{
КОМПЛЕКСНА ЗАБУДОВА І АРХІТЕКТУРНО-ХУДОЖНС ОФОРМЛЕННЯ ІВАНО-ФРАНКІВСЬКА В ЧАСИ "РОЗВИНУТОГО СОЦІАЛІЗМУ"
}

\author{
Oleh MALIARCHUK \\ Ivano-Frankivsk National Technical University of Oil and Gas \\ Department of Philology, Translation and Interpreting \\ Oryshchak St., 7, 77300, Kalush, Ivano-Frankivsk region, Ukraine \\ e-mail: oleg.malyarchuk@gmail.com
}

\begin{abstract}
Summary
The article describes the changes that took place as a result of the socialist industrialization of the western regions of the Ukrainian SSR by the example of the Ivano-Frankivsk region and related urbanization. The architecture of the city of Ivano-Frankivsk (Stanislavov, Stanislav) has absorbed features of different historical epochs. Architectural features different from all other styles as well as the scale of development characterized the Soviet period in the history of the city. The urbanization of Ivano-Frankivsk, Ternopil, Chernivtsi, Uzhhorod, and especially Lviv, is unique in its historical experience. It was "overdue" and was preceded by a radical military and postwar change in the ethnic and social composition of the population of cities where Jews and Poles were the dominant majority. The rapid increase in urban population of the western region of the republic was at the expense of the Ukrainian rural population. Among other major Ukrainian cities, Ivano-Frankivsk was notable for being one of the few regional centers (inferior to Lviv), that was Ukrainized, and played a decisive role in the national-religious movement of the second half of the 1980s.

The purpose of the study is to analyze in the historical context the specifics of architectural and artistic design, improvement of the city of Ivano-Frankivsk during the rule of the Soviet totalitarian system ("developed socialism"), successes and miscalculations. Objectives: 1) to prove that irreparable damage was caused to the historic part of the city as a result of Soviet reconstruction. Many old buildings could have been in operation for decades, after preventive repairs. They reiterated the fate of their former owners, who were physically destroyed; 2) to generalize the gains and disadvantages in the practice of housing, industrial and communal construction on the example of frequent cases when in the territory of the new building (quarters, neighborhoods and even entire settlements) the inhabitants were not provided with the most necessary elements of improvement. Significant disadvantages were allowed in the landscaping business.

To develop the topic, the authors used a whole group of scientific methods: the principles of objectivity and historicism, which involve consideration of particular phenomena and processes in their development and close connection with the system of relevant social relations; historical facts are considered against the backdrop of political processes, which involves the use of a method of comparative analysis, which clarifies the essence of many significant events for Ukrainian socio-political thought. Design and construction organizations while constructing residential complexes did not always take care of the conservation of natural relief, vegetation, green space. The public carried out systematic work on the improvement of cities, towns and villages. The Party-Soviet authorities tried to chalk up all the achievements. The regional center of IvanoFrankivsk gained the glory of a beautiful city. At one time, it won prizes in urban competitions. This glory was preserved and multiplied by the city's inhabitants, despite the adverse political conditions of the totalitarian system through creative approach to the renewal and expansion of the city, attentive and careful attitude to the existing capital buildings and nature.
\end{abstract} planting.

Keywords: architectural styles, Ivano-Frankivsk, complex development, residential areas, landscaping,

\section{REFERENCES} Ukrainian).

Akhmetenko, D. (1977 January, 14). The city is the unique complex. Prykarpatska pravda (in

Baran, V. (2003). Ukraine: contemporary history (1945-1991). Lviv: Instytut ukrainoznavstva im. I. Krypiakevycha NAN Ukrayiny (in Ukrainian).

Derzhavnyi arkhiv Ivano-Frankivskoi oblasti [Ivano-Frankivsk Region State Archive] (in Ukrainian).

Demianchuk, S. (1976, June, 13). The course for romance. Prykarpatska pravda (in Ukrainian).

Diatlov, D. (1976, March, 30). Quality sheet. Prykarpatska pravda (in Ukrainian).

Housing is a good of the people. (1975, May, 13). Prykarpatska pravda (in Ukrainian).

Hometown growth. (1965, November, 30). Prykarpatska pravda (in Ukrainian).

Humen, Y. (2008). Urban-ecological problems of the Western region of Ukraine in 1960-1990: historical aspect. Ternopil: Vektor (in Ukrainian). 

Ukrainian).

Klapchuk, V. (2013). Minerals in Galicia: mining and processing. Ivano-Frankivsk: Foliant (in

Let us protect our homes. (1967, December, 10). Prykarpatska pravda (in Ukrainian).

Maliarchuk, O. (2015). Socio-economic processes in the western region of the Ukrainian SSR (1964-1991). Ivano-Frankivsk: Symfoniia forte (in Ukrainian). Ukrainian).

National economy of Ivano-Frankivsk region. (1970). Statystychnyi zbirnyk. Lviv: Statystyka (in

Polityko, P. The city is growing up. (1975, April, 20). Prykarpatska pravda (in Ukrainian).

Popychenko, L. (1975, July, 20). Like at home. Prykarpatska pravda (in Ukrainian).

Vasiuta, S. (2000). Soviet ecocide in Ukraine: historical sources and difficulties of overcoming. Ternopil: Aston (in Ukrainian). 